\title{
Györgyi BARTA*
}

\section{GEORGES BENKO AS I KNEW HIM}

Our first meeting was probably in 1987 or 1988, when Georges Benko came to Hungary. Later I visited him at the Sorbonne in rue Saint-Jacques, where he was a teacher. From then on he sometimes sent me packages full of books, copies of studies, most recent literature in regional science and economic geography, material practically unavailable in Hungary at the time. Without being asked, he gave me an incredibly big helping hand.

In 1991, just before it was to be published by Masson (now ElsevierMasson), Georges sought permission from the publisher to have a slightly abridged version of Géographie des technopôles translated and published in Hungary. I translated his manuscript together with my colleagues. During my longer fellowship stay in Paris, Georges and I worked together, improving and completing the Hungarian translation chapter by chapter. Back at my Hungarian workplace (Centre for Regional Studies, Hungarian Academy of Sciences) we finished editing the Hungarian version of Benko's book (Technologiai parkok és technopoliszok földrajza) whose publication in 1992 was financed by the Soros Foundation. The first part of the book deals with the economic crisis of the 1970s, industrial restructuring, innovation and R\&D, the developmental path of technology and with the emergence of industrial districts. In the second part, Silicon Valley and other famous American cases were described as the origins of technological parks, and how the Japanese, British and French industrial policies followed the American model and created networks of technological parks. Today Benko's book has lost nothing of its relevance. In the middle of the 1990s, Hungarian regional planning used its collected knowledge effectively to map out the national industrial parks programme, and 10 years later, a new

\footnotetext{
* Györgyi BARTA, Academy of Sciences, Centre for Regional Studies, Budapest, Hungary, e-mail: barta@rkkmta.hu.
} 
regional development plan based on the growth pole, the so called 'pole programme' was launched with the assistance of the French government. This programme aimed at the development of regional centres by fostering cooperation of leading enterprises, local universities, research institutes and the government.

Another of his books translated into Hungarian was La science régionale which appeared in 1998 (Regionális tudomány). Despite its roots in the 19th century, regional science is one of the newer fields in the social sciences. It examines how people change their space. It integrates, among others, economics, geography, history, sociology, law, political sciences, urbanism and anthropology. In its approach this science is truly interdisciplinary. In his book Georges Benko clearly defined the place of regional science within the social sciences, and at the same time he showed its inner logic.

In Hungary, these ideas were adopted very quickly, and this important book was published in Hungarian only a year later. It was no coincident. In the 1980s and 1990s, regional science had become an acknowledged discipline in Hungary. Publishing the Hungarian version of Benko's book was assisted by György Enyedi and György Horváth, both belonging to the founders of the respective institutions and a dedicated review in Hungary. Benko's book is still relevant as regional science continues to be debated: The latest issue of the Hungarian review Tér és Társadalom (Space and Society) contains a contribution by Imre Lengyel querying the progress of regional science.

In 1997 Benko contributed another study which was translated for Tér és Társadalom: Ways of Regional Development: from Globality to Locality. This study summarised the most important conclusions of his famous book Les régions qui gagnent, and it dwelt on the discussion about what explains the successfulness of a region best: the influence of the international division of labour or endogenous development? The debate about global vs. local development is still going on and has its impact on the theoretical base for regional development plans.

Georges Benko ranked among the most eminent theorists of regional science. Unfortunately, he never focused on the East-European political transition at the beginning of the 1990s, in general, nor on the Hungarian case, in particular. Yet his very modern theoretical knowledge would have been needed in Hungary in order to really establish regional science there. Nevertheless, his books and studies had an important influence on those Hungarian intellectuals who dealt with regional science. We would have liked to involve Georges Benko in the Hungarian scientific life much more. György Enyedi invited him for a visit hosted by the Hungarian House of Professors - in the mid-1990s. Later I proposed him for member of the editorial board of European Spatial Research and Policy, and he accepted. His long tormenting illness and untimely death cut short the time for our cooperation. Georges Benko was always a helpful, good friend, as was his wife, Judith Lazar, a sociologist of renown. 


\section{REFERENCES}

BENKO, G. (1991), Géographie des technopôles, Paris: Masson.

BENKO, G. (1992), Technológiai parkok és technopoliszok földrajza (Geography of the Technological Parks and Technopolises), transl. and ed. G. Barta et al., Budapest: MTA Regionális Kutatások Központja.

BENKO, G. and LIPIETZ, A. (eds), (1992), Les régions qui gagnent, Paris: Presses Universitaires de France.

BENKO, G. (1997), 'Ways of Regional Development: From Globality to Locality' (A regionális fejlődés útjai: globálistól a lokálisig), transl. G. Barta, M. Králik, Tér és Társadalom, 2, pp. 1-16.

BENKO, G. (1998), La science régionale, Paris: Presses Universitaires de France.

BENKO, G. (1999), Regionális tudomány (Regional Science), transl. D. Csizmadia, Gy. Enyedi, Pécs-Budapest: Dialóg Campus Kiadó.

LENGYEL, I. (2010), 'The Progress of Regional Science' (A regionális tudomány 'térnyerése'), Tér és Társadalom, 3, pp. 11-41. 